\title{
A structural and systematic account of the genus Struvea.
}

BY

\author{
GEORGE M URRAY, F.L.S., \\ Senior Assistant, British Museum;
}

AND

LEONARD A. BOODLE, A.N.S.S., F.L.S.

With Plate XVI.

$\mathrm{T}$ HE genus Struvea was founded by Sonder in 1845 , in a paper ${ }^{1}$ in the Botanische Zeitung for that year, in which he described the new algae collected by Preiss in his Australian travels. The name was chosen in honour of H. de Struve, Ambassador from Russia to the Hanseatic Towns, and a patron of Natural History. The only species described was $S$. plumosa, Sond., subsequently figured by Kützing ${ }^{2}$ and later by $\mathrm{Harvey}^{3}$. In the same volume Harvey figures the next species known under the name S. macrophylla, both forms being remarkable for their graceful habit. We have examined Harvey's specimens of $S$. plumosa in the British Museum, and Dr. Perceval Wright with great kindness sent us for examination not only the unique of $S$. macrophylla, known to Harvey at the time of its publication, but also a specimen collected later in the same region (West Australia) by Mr. G. Clifton. Harvey's unique is a bleached specimen, but the later one retains its

1 Nova Algarum genera et species, quas in itinere ad oras occidentales Novae Hollandiae, collegit L. Preiss. G. Sonder, in Botan. Zeit. 1845, p. 49.

2 Tab. Phyc. Bd. vi. pl. 90.

3 Phyc. Austr. vol. i. pl. $3^{2}$.

[Annals of Botany, Vol, II. No. VII. November 1888.] 


\section{Murray and Boodle.-A structural and}

green colour. Kützing describes and figures ${ }^{1}$ two forms, which he names $S$. scoparia and $S$. delicatula. They were both collected by Vieillard in New Caledonia. Dr. Suringar, the happy possessor of the. Kützing Herbarium, has been good enough to lend us the type specimen of S. scoparia, and, from an inspection of it, we have no hesitation in excluding it from the genus. It agrees in all respects with the neighbouring genus Apjohnia, and though hardly in perfect accord with $A$. laete-virens, Harv., we have not sufficient reason to separate it from that form. $S$. delicatula is no doubt a Struvea, and from a comparison of Harvey's specimens of his Cladophora? anastomosans ${ }^{2}$ (published seven years before) there appears to be equally little doubt that it too belongs to the same species. Dr. Grunow has kindly called our attention to certain Ceylon specimens collected by Mr. Ferguson (No. 98), and it is right to add that the examination of a series of these has materially helped us to this conclusion, in which we find we have been anticipated by $M$. Crouan ${ }^{3}$. The next form recorded was collected by the 'Challenger Expedition' from thirty-one fathoms off Bermuda, and described by Prof. Dickie ${ }^{4}$ under the name of S. ramosa. Since then Drs. Piccone and Grunow have published $^{5}$ a form from the Canary Islands to which the name was given of $S$. anastomosans (Harv.) var. canariensis. Dr. Piccone mentions, in a note, that he intended to make this plant the type of a new genus to be called Cormodictyon, but he wiscly gave way to the eminent Dr. Grunow, who insisted on its being a Struvea. The authors, however, are mistaken in quoting $S$. anastomosans, Harv., since the Cladophora anastomosans of Harvey, although published previously, is none other than S. delicatula, Kütz. In the second place, Dr. Grunow, never having seen specimens of $S$. ramosa, Dickie, was thus prevented from placing the

\footnotetext{
1 Tab. Phyc. vol. xvi. p. I, Tab. $2 . \quad{ }^{2}$ Phyc. Austr. vol. ii. pl. IoI.

3 Mazé et Schramm, Algues de la Guadeloupe.

' Linn. Soc. Journ. Bot., vol. xiv.

5 Crociera del Corsaro. Alghe, $188_{4}$.
} 
systematic account of the genus Struvea. $\quad 267$

Canary Island form under it as we have now done, after inspecting a specimen kindly sent us by Dr. Grunow. In I 878 Zanardini described ${ }^{1}$ a very beautiful minute form collected by Dr. Beccari, in New Guinea, under the name of S. tenuis. We have to thank Dr. Beccari for the opportunity of examining this species.

Passing over for the present the hitherto unpublished form sent us by Dr. Grunow, under the MS. name of S. delicatula, Kütz., var. Caracasana, Grun., we now come to what is perhaps the most striking and beautiful of all forms of Struvea. Dr. J. E. Gray, in his paper on the genera Anadyomene and Microdictyon ${ }^{2}$, established the genus Phyllodictyon to include a very remarkable specimen collected by $\mathrm{Mr}$. Menzies in the Gulf of Mexico in 1802 , and preserved in the Herbarium of the British Museum. This very fragile specimen, large as it is ( $\mathrm{I}$ foot by 3 inches), is but a fragment of the whole plant, as the remains of the stalk clearly show. It was probably about an inch higher and six or seven inches in breadth. (See reduced Fig. $4 a$.) Though so much larger than $S$. macrophylla the texture of the frond is even more delicate.

Dr. Agardh, in his recent monograph of Siphoneae, gives an account of the genus as known to him at p. 108. He merely enumerates the four species and one variety known to him (some of them by name only), and records his doubt as to whether they all belong to the same genus. So many more forms have become known to us, and we have obtained access to so much material, that we venture to hope that the following account may in some degree improve upon the unsatisfactory state in which Dr. Agardh was compelled to Icave the genus.

THE STALK consists of a single cell from its earliest stages up to the time of formation of the frond, when a transverse wall is formed a short distance below the base of the frond. The form of the stalk, however, differs greatly according to the species.

1 Phyceae Papuanae Novae, in Nuovo Giom. Bot. Ital. x.

2 Journ. Bot. 1866, p. 69. 


\section{Murray and Boodle.-A structural and}

In $S$. plumosa (Fig. I $a$ ) the stalk is at first club-shaped with a smooth and delicate wall in which, as well as in the nature of its contents, it very closely resembles some species of Valonia (Fig. 1 b). At a later stage it becomes annularly corrugated below, while the apex remains smooth and obtuse. In this condition it increases in length, and ultimately the upper part becomes prolonged into a slender corrugated filament, from the apex of which a cell is cut off which, by subdivision, produces a series of ten or twelve cells one above the other, which, by their branching, give rise to the whole of the frond. This statement is derived from Harvey's description ${ }^{1}$, which we have been unable to verify as regards the first stages in the formation of the frond, because the specimens of $S$. plumosa accessible to us do not include any of the exact age required. The mature stalk tapers slightly at both ends, and is corrugated throughout (Fig. I $c$ ). By making a longitudinal section of a well-developed frondless stalk, we came to the same conclusion as Harvey and Agardh, viz. that the cavity of the stalk is not interrupted by any transverse walls. The outer wall is so much thickened, and in the older specimens encrusted with a Melobesia in addition, that without making a section one would probably be unable to detect septa if they were present. The constrictions are only inflexions of the membrane. The wall is formed of a great number of layers, and when cut or otherwise roughly treated the inner layers tend to break up into fibrils, as observed by Agardh ${ }^{2}$ in the nearly related genera Apjolnia and Chamaedoris. A similar fibrose structure is described by us in the present volume (p. 17I), in a paper on Spongocladia; it is of course connected with the striations seen in surface view in all these cases. The older stalks are incrusted in various degrees with calcareous algae, chiefly a Melobesia, which Harvey refers to as a thin coating of calcareous matter, making it one of the characters of the genus. According to Leitgeb ${ }^{3}$ the

1 Phyc. Austr. pl. $3^{2}$.

2 Monogr. Siphon. p. 107.

Q Quoted from Rot. Zeit. 1888, No. 14 ; Sitzb. Kais. Akad. d. Wiss. in Wien, Bd. $\mathrm{g}^{6}$. 
incrustation of Acetabularia consists chiefly of calcareous algae, just as in the present genus.

We have seen only one branched specimen in S.plumosa, in which two stalks sprang from a very short common sac-like base. In S. macrophylla (Fig. 2 a) the stalk tapers slightly from the middle towards each end, is corrugated throughout, and resembles that of $S$. plumosa; and it is presumable that the stages of development are the same in the two species, for thcy seem nearly related to one another.

In S. ramosa the stalk has a very different appearance from that of the two species just mentioned. It is here filiform and of about equal diameter throughout, except for a few transverse corrugations which occur usually at the base of a stalk, but are sometimes absent altogether and would be overlooked at the first glance owing to the small diameter of the stalk. The stalk is often branched in this species, in which case the branches generally show a few corrugations at their bases. Branching is generally opposite, Fig. $3 b$ being a typical example. The branches here are of about equal value, but in some specimens the central filament branches again. Before the frond is formed the stalk is simply an erect cylindrical unicellular tube. Dickie, after describing S. ramosa, mentions the presence of a 'thin, reddish, calcareous coat at the lower part' of the stipes, as one of his reasons for referring it to the genus Struvea. This calcareous coat is however, as in S.plumosa and S. macrophylla, evidently due to incrusting algae.

In S. pulcherrima (Fig. $4 a$ ) the stalk is filiform, cylindrical, and smooth (where it is visible, being mostly enveloped by a short tufted red sea-weed-no Melobesia being present). It is apparently branched into three filaments, each of which is again divided into four, but as the whole system bears only a single frond, it is better to regard the branches as forming the lower part of the frond. In S. ramosa the stem was regarded as branched, because each of its divisions bore a perfectly distinct frond; but taking a single frond of this species, it is seen that the filament bearing it divides into three branches, which remain simple for a short distance before, 


\section{Murray and Boodle.-A structural and}

entering, or rather forming, the frond. If these three branches were increased in length below the frond they would produce an arrangement approaching that of $S$. pulcherrima.

$S$. tenuis has a very minute stalk (Fig. $5 a$ ), which bears a greater proportion to the frond as to length than is the case in S. plumosa. It is smooth with a delicate wall, and below the frond there is a septum in the usual position, i.e. at a distance below the frond a little greater than the length of the lowest cell of the midrib. The stalk is unbranched except in one specimen, where it is forked about half way up; one of the branches bears a frond, but the other is simple.

The stalk of $S$. delicatula is never corrugated. It is simple or branched, and usually of about the same diameter as the midrib (Figs. $6 a, 7 a, 8 a$ ).

THE ROOTS of S.plumosa (Fig. I $a$ ) are given off laterally from the lowest quarter-of-an-inch of the base of the stalk; they are very tenacious, branched, irregularly septate, occasionally transversely corrugated, bearing discs or tufts of rootlets here and there which are sometimes very like the organs of attachment to be described in the frond. The roots contain a great number of starch-grains and sometimes chlorophyll, even in the ends of their branches; they become very much entangled and matted together, so that the stalks, which grow together in tufts, can often only be separated by tearing some of their roots.

It seems very probable that vegetative multiplication may take place by some of the roots assuming the character of creeping rhizomes, which produce vertical frond-bearing branches.

In support of this it may be mentioned that a root of $S$. plumosa connected with a frond bore a vertical branch which, though small, was very like a young stem. S. macrophylla has well-developed roots, but they have relatively thin membranes and an almost entire absence of cross walls, but numerous thizoid attachments. The roots of $S$. delicatula are generally very septate and irregular (Fig. $8 \mathrm{c}$ ). S. ramosa has very slight development of roots in the specimen where the 
base of the stem was best seen. In S. tenuis they were hidden, and in S. pulcherrima they were not very clear owing to the fragments of shell, etc. to which they were attached.

THE FROND of S. plumosa is formed, according to Harvey, by the subdivision of the apical cell into a vertical series of cells, each of which produces from its shoulders two opposite branches, at first free and pectinate, then once and again pinnulate, the pinnulae 'anastomosing' and producing the network. Agardh supposes that an apical cell is repeatedly cut off and a pair of branches formed below it each time. If this be so, and Harvey's Fig. 4 makes it probable, then this species differs in the mode of development of its frond from that of S. tenuis, which is described below.

The filaments composing the frond of S. plumosa show striation of their walls very well (Fig. $\mathrm{I} h$ ); it is seen equally well in the young stalk before it becomes too much thickened. Longitudinal and transverse striations are easily observable. The former appear to be more numerous in the outer layers of the cell wall, the transverse ones in the middle layers, and the longitudinal again in the innermost. Fig. I $h$ shows these striae in one of the cells of the midrib. In some cases only the longitudinal striations are to be seen. Longitudinal and transverse striae of this kind are mentioned by Thuret ${ }^{1}$, and were held by him to be characteristic of the genus Conferva, but they have since been described in other genera, as mentioned above, in connection with the stalk.

The structure of the frond of S. plumosa is very regular, the primary veins or pinnae being given off in opposite pairs from the midrib at an angle of about $60^{\circ}$; they remain parallel to one another for some distance and then each curves upwards and inwards, attaching itself by its apex to the lower side of the similarly curved pinna next above it.

The frond is regularly crenate, its margin being formed by the curved ends of the pinnae, which produce no branches from their outer side where they form part of the margin.

1 Annales des Sciences naturelles, Bot. sér. 3, Tome III (1845), p 274. 


\section{Murray and Boodle.-A structural and}

Thus the tips of the pinnae form exceptions to the rule of opposite branching which prevails elsewhere in the frond of this species, because they give off pinnules on their upper side only (Fig. I $e$ ). The pinnae are constricted at regular intervals so as to appear to consist of a series of segments about twice as long as broad separated by transverse walls. To prove that the apparent septa were not merely annular thickenings, a filament (allowed to swell up in water) was torn at one of the constrictions, and the cross wall was seen to bulge out under the microscope when the filament was pressed. Below each transverse wall of a pinna two (except at the apex) opposite pinnules are given off, which lean slightly forward and attach themselves to the next pinnae on their respective sides (Fig. I $e$ ). In the lower part of the frond they become constricted at a varying number of points (dependent on the length) and form transverse walls at the points of constriction. In the upper part of the frond the pinnules give off short unicellular branches below some of their septa, thus increasing the complexity and compactness of the frond. Owing to the comparative shortness of the cells which form the pinnae, the pinnules are inserted pretty close to one another, and as they are directed slightly forwards (i. e. towards the apex of their pinna), they cross one another, so that, when looking at the frond, one sees one series of pinnules at the surface partly covering another series below. The length of the pinnules is about 3-5 times their diameter, their articulations being about I $\frac{1}{2}$ times. They are relatively thick, so that in a mature frond there are hardly any interstices to be seen, on account of their overlapping arrangement. The general arrangement of the pinnules in the specimens we have examined is a little different from that shown by Harvey ${ }^{\text {. }}$.

The mode of attachment of the pinnae and pinnules has now to be described. When a pinnule has by its growth brought its tip into contact with another part of the frond, it forms at its apex a special organ of attachment which we propose to call a tenaculum (Fig. I $f$ ).

\footnotetext{
1 Phyc. Austr., Tab. $3^{2}$.
} 
The tenaculum consists of a ring of radiating branched rhizoids which surround the disc of contact between the apex and the wall of the pinna. The mode of formation of this seems to be that the tip of the pinnule becomes somewhat flattened on the wall of the pinna, and then, from the outermost region of contact, puts out a number of small radiating rootlets which creep along the surface of the pinna, and branch so as to form a compact rosette-like structure, which adheres to the surface of the filament and fixes the pinnule in position.

Careful focussing has led us to believe that these rootlets are entirely superficial, never penetrating the cell-wall, but adhering to it probably by some process like that by which the root-hairs of higher plants adhere to particles of soil.

These organs appear to be formed only in response to contact, like the adhesive discs of Ampelopsis, and they are nearly universally terminal in position, only a single lateral tenaculum was seen among all the species. A transverse wall is nearly always formed in the pinnule at a short distance from the apex, thus cutting off a sub-globular terminal cell which bears the ring of rootlets (Fig. I $f$ ). This wall is evidently connected with the formation of the rootlets, for it seems to be formed only when attachment takes place. A possible function of this septum is to prevent too great loss of contents in case of injury to the delicate rootlets. Fig. $3 e$ shows a filament of S. ramosa bearing two of these organs at its apex; one or two similar cases were seen in S. plumosa.

As occurring in Valonia fastigiata, Harv., Agardh ${ }^{1}$ mentions certain structures, which he terms fibulae. These seem from his description to have the same function as the organs which we have described under the name of tenacula, in our opinion a more appropriate word. His figure (Tab. I, Fig. 5) of these organs shows that they differ a good deal in appearance from those of Struvea, in being lateral and in the different character of the rootlets (if one can so call them), though they

1 loc. cit. p. 94 . 


\section{Murray and Boodle.-A structural and}

serve the same purpose of attaching branches to one another. Agardh refers to the well-known similar structures in several of the encrusted Siphoneae (Udotea, etc.), though he believes that among these latter their function may sometimes be that of attachment, and may sometimes be connected with the deposition of lime. We examined a piece of Microdictyon Velleyanum, to see if similar organs were present in that genus, and found that an apex of a filament, when it comes into contact with another filament, forms crenations round the edge of contact, which are sometimes sufficiently pronounced to be termed rhizoids, but the attachment, which is very firm, must be chiefly due to cohesion between the filament-surfaces, which is here sufficient without increase of contact-surface by formation of long rootlets like those of Struvea. Tenacula occur also in Spongocladia, where they resemble those of Struvea.

In describing species of Struvea, Harvey ${ }^{1}$ and Dickie ${ }^{2}$ both speak of 'anastomosis' of filaments, and Harvey further mentions it among the generic characters. This word cannot be correctly applied to the frond of Struvea, for though the filaments become attached to one another by means of tenacula, there is no resorption of the double membrane which separates the cavities of the cohering filaments. The attachment, however, is sometimes very firm, as in S. delicatula, described below.

The frond of S. macrophylla (Fig. $2 a$ ) bears a slight general resemblance to that of $S$. plumosa, but differs in the mode of branching of the filaments which compose it and in its much greater size. The two specimens of this species differ somewhat from one another in detail. The branching and arrangement of the filaments is almost precisely similar, but the frond of the one ${ }^{3}$ is oblong-oval, cordate, and strongly crenate, while the other (Fig. $2 a$ ) is oblong-elliptical with a very slightly crenate margin. The midrib is very distinct, and of about the same diameter as the upper part of the stalk. The primary branches or pinnae are given off oppositely from the midrib

\footnotetext{
1 Phyc. Aus., Pl. 7 and 32.

${ }^{2}$ Linn. Soc. Journ. Bot. vol. xiv.
} ${ }^{3}$ Harv. Pl. 7 . 
at angles varying, from below upwards, from $90^{\circ}$ to about $45^{\circ}$. The secondary branches are very regular and so arranged as to produce zigzags connecting each pair of primary branches. The tertiary branches run parallel to the primary, three or four bridging over the V-shaped space between two pinnules, and enclosing elongated meshes.

Quaternary branches are formed here and there. The frond of the bleached specimen, which Harvey described, is a good deal incrusted with calcareous algae, but this may have taken place after the death of the plant.

In $S$. ramosa the frond has a midrib and pinnae, which are rather inconspicuous as their diameters are not much greater than that of the pinnules (Figs. $3 a$ and $3 c$ ). The lowest cell of the midrib and the lowest cell of each of the two basal branches are elongated in the mature (?) frond. The branching in some of the specimens is very regular. Two or four branches are given off from the top of each cell of the midrib, and their pinnules become attached to one another and to the pinnae and midrib, so as to form a reticulum which has usually triangular meshes (Fig. $3 \mathrm{c}$ ). The margin of the frond generally has projecting pinnae and pinnules, which probably shows that the specimens are not mature. The regularity of the reticulum varies very much in the different specimens, and sometimes in different parts of the same specimen. Similar irregularity is seen in $S$. delicatula and in S. tenuis, where it is sometimes due to injuries, but at other times merely to change in the angle of branching or suppression of some of the branches, where no injury is apparent. Branching in $S$. ramosa often takes place before the formation of a transverse wall, as shown in Fig. $3 f$, but that septa are ultimately formed was proved by examining the ends of filaments which had been torn up, as was done in S. plumosa. The tenacula are here very much like those of $S$. plumosa, but, like the whole of the frond, they have thinner walls than the latter species. The rhizoids are well developed, and very delicate (Fig. $3 d)$. By focussing the cell-wall at the apex of the tenaculum, three or four pits with granular contents are often seen. They 


\section{Murray and Boodle.-A structural and}

must be the mouths of tubes which, by their repeated branching, produce the whole of the rootlets.

In addition to these usual organs of attachment, there are also remarkable structures of the kind at the bases of some of the filaments of the frond, which in shape resemble the sporangia of Botrydium (Fig. $3 h$ ). They have evidently been produced by the formation of a small wart-like outgrowth from the base of a branch just above its basal wall. The outgrowth then grew downwards parallel to the filament, producing a neck-like prolongation which curved inwards and came into contact with the surface of the filament below the transverse wall, and then threw out a fan-shaped mass of branched rootlets on the wall. These organs occur in the specimen examined at the point of origin of the frond, where the stalk divides into three filaments, each of which has two of these organs at its base (Fig. $3 \mathrm{~g}$ ); there are three or four at each of the next two points of branching of the midrib, and, at a point in the stalk where there is a transverse wall, five or six of these clamps connect the part of the stalk above the cross-wall with that below.

Similar bodies were detected at the base of the frond of Dr. Piccone's specimen, but nothing like them has been seen in the other species of Struvea. From the arrangement of contents these bodies do not seem to be cut off from the cavity of the filament which produces them.

The frond of S.pulcherrima, as stated above, is supported by three main filaments. Its outline and dimensions cannot be determined, owing to the fragmentary nature of the specimen, but the probable shape is that given in Fig. $4 a$, and the size would be about 10 inches in length by 6 to 7 inches in breadth. Each of the three filaments branches into four; these remain simple for a short distance and pass into the frond, where they are traceable as veins, which in their turn produce veinlets, and the branching is repeated several times, so that, by the attachment of the ultimate branches to each other and to the veins, a very perfect network is formed (Fig. $4 b$ ). The veins and veinlets generally give off two or four branches just below their transverse walls, but here and there 
an arrangement occurs which reminds one of the branching of the main filaments in Anadyomene. One of the cells is club-shaped, and from its swollen end gives off five or seven branches of about equal value, though smaller than itself, and separated from one another by nearly equal angles.

The frond appears septate throughout; a small piece was tried, as in S. plumosa, and found to have real transverse walls.

The tenacula have very well-developed rhizoids, and adhere very closely to the filaments.

S. tenuis (Fig. $5 a$ ) has a shortly ovate cordate frond with 5-7 pairs of pinnae, which form a crenate margin by their incurved apices, and give off pairs of pinnules, mostly united with one another in a very regular manner, the apex of one attaching itself to the middle of another (see Fig. $5 b$ ). Transverse walls appear to be formed rather late: thus in Fig. $5 c$ there are only one or two present, the other transverse marks being slight constrictions.

The very regular arrangement seen in Fig. $5 b$ does not seem to be constant in this species, for in another specimen the mode of attachment varies in different parts of the frond; one pinnule gives off two branches, and some of the pinnules attach themselves to the pinnae instead of to each other. A very early stage in the formation of the frond is seen in Fig. $5 d$, which shows five pairs of protrusions below the apex, and below them a constriction, which will probably be the point of formation of the septum in the stalk below the frond. Although slight creases are seen in one or two places, we think there is no doubt that the whole is a single cell. This agrees with the late formation of the transverse walls in the pinnae. In S.plumosa the pinnae form their transverse walls before giving rise to pinnules, so it is very likely that in the formation of the frond cell-walls would precede the branch protusions, in that species, as described by Harvey.

S. delicatula (Fig. $6 a$ ) is the most variable species of the genus. On comparing Kuitzing's figure of this species with Harvey's figure of his Cladophora? anastomosans one would not be much disposed to unite the two, but in looking through 


\section{Murray and Boodle.- $A$ structural and}

a large number of the specimens of this species collected by Ferguson, we found that the fronds exhibited almost every degree of reticulate cohesion between the two types, and equally wide variations in the angle of branching, size of ultimate branches, etc., so that it is hardly possible to make a diagnosis to suit all the specimens.

The branching in the frond of most of Harvey's specimens is rectangular, and the reticulum very perfect; this is also the case in several of Ferguson's specimens (Fig. 6 b), but in many of the latter the cohesion of branches is very imperfect, whole pinnae with their pinnules remaining free from one another or united only at one or two points. The cohesion evidently begins at different times in different individuals, for in some the fronds show a reticulate structure when they are still very small, but in others the pinnae grow to a considerable length before the pinnules become attached, thus producing a frond like that in Kützing's figure; but we are of opinion that these forms would, when older, become like the more reticulate forms. The angle of branching is sometimes acute, but when the pinnae have become united with one another by means of their pinnules, if, as is probable, growth ceases in the pinnae in acropetal order, they become straightened out so as to stand at right angles to the midrib. The lower parts of the frond are often, as in S. macrophylla, more rectangular than the upper.

The specimens of S. delicatula, var. Caracasana (Fig. 7 a), have regularly bipinnate fronds, and the pinnules have only become attached in one or two places (Fig. $7 b$ ), but, from the mode of attachment, the fronds must be pretty nearly mature.

One very anomalous form (Fig. $8 a$ ) was collected by Ferguson; it has very upright branches, and we should have classed it as an oppositely branched Cladophora, but for the following facts:- the character of its roots and stalk is exactly the same as that of the specimens of the Struvea delicatula, with which it is associated, its plan of branching (although more upright) is very much the same, and here and there the 
systematic account of the genus Struvea. 279

branches are united by terminal organs of attachment precisely the same as the tenacula of $S$. delicatula. The branching takes place oppositely, and in one plane, but as the branches are mostly free they become more or less irregularly arranged when dried (Fig. $8 b$ ).

S. delicatula often grows in tufts with the fronds attached to one another by some of the pinnules of one adhering to the other frond by their tenacula. In one of the erect forms the end of a branch has attached itself by a tenaculum to a small piece of shell, which had fallen on the top of the tuft.

The attachment of the branchlets must be very firm, because, when two pinnules are torn apart, the tenaculum of the one sometimes tears off the outer layers of the wall of the other. Prolification of filaments sometimes occurs in S. delicatula, as seen in Fig. $6 d$, where the old filament must have broken off and a transverse wall helped in the formation of a new filament.

We have been unable to find any traces of reproductive organs in any of the species of Struvea. In S. plumosa Kützing observed in one of the filaments ${ }^{1}$ some dark green granular spherical bodies which he calls 'Keimzellen (?).' They may be reproductive bodies, of some kind, but they remind one of the often spherical masses into which the protoplasm and chlorophyll of a cell of Cladophora frequently resolve themselves when the wall has been injured and the turgidity destroyed.

Until the reproduction of Struvea has been discovered its systematic position must remain doubtful. It is indissolubly linked with Chamaedoris and Apjohnia, and the evidence before us seems to point to this group as occupying a position among Siphoneae (sensu Agardh) near to Valonia, but connecting this series of forms with other green algae, such as Cladophora and Spongocladia. 


\section{DISPOSITIO SYSTEMATICA.}

Struvea Sond. Bot. Zeit. (1845), p. 49.

Alga viridis, marina, erecta, stipitata, flabelliformis. Stipes simplex vel ramosus, radicatus, monosiphonius, continuus, in aetate majore reticulo flabelliformi, costato, coronatus. Reticulum ex filis confervoideis plus minusve articulatis, pinnatis, apice per tenacula radicantibus, evolutum.

Syn. Phyllodictyon, J. E. Gray, Journ. Bot. (I866), p. 69. Pterodictyon, J. E. Gray, loc. cit., p. 70. Cormodictyon, Piccone in Crociera del Corsaro (1884), p. $2 \mathrm{I}$.

I. Str. plumosa ${ }^{1}$, Sond., loc. cit., p. 50. Stipes rugosus, reticulo oblongo-ovali ( $\mathrm{I}-2$ uncias longo) crenato, coronatus; filis 2-3-pinnatis; articulis pinnarum diametro 2-3-plo, pinnularum sesqui-longioribus. Harv. Phyc. Austr., Tab. xxxii. Kütz. Tab. Phyc., Bd. vi. Tab. go.

Hab.ad oras occidentales Novae Hollandiae legit Preiss, Harvey! Clifton.

2. Str. macrophylla, Harv. Phyc. Austr., Tab. vii. Stipes rugosus, reticulo oblongo-ovali grande, spectabili (4-6 uncias longo, $2 \frac{1}{2}$ uncias lato) crenato, coronatus; filis pluries pinnatis, articulis pinnarum 5-6-plo, pinnularum 3-4-plo, diametro longioribus.

Hab. ad oras occidentales Novae Hollandiae legit Mrs. Drummond! Clifton!

3. Str. ramosa, Dickie, in Linn. Soc. Journ. Bot., vol. xiv, p. 316. Stipes rugosus, sursum opposite ramosus, reticulis subellipticis; filis tripinnatis, articulis inferioribus pinnarum 7-8-plo, superioribus 3-4-plo, diametro longioribus.

Syn. Struvea anastomosans, Harv. (sic.) var. canariensis, Picc. et Grun. in Crociera del Corsaro, Genova (1884), p. 20.

Hab. ad Bermudam, ex profundis extracta. H.M.S. 'Challenger'! et ad insulas Canarienses legit Piccone!

1 We have seen, in the Edinburgh Herbarium, a type specimen of $S$. plumosa collected by Sonder. The plants, though younger, have very much longer stalks than Harvey's, and an examination of the young frond confirms the view expressed above as to its development. 
systematic account of the genus Struvea. $28 \mathrm{I}$

4. Str.pulcherrima, nob. n. sp. Stipes laevis reticulo oblongo, cordato, tricostato, maximo (10 uncias longo, 6-7 uncias lato) coronatus; filis iterum atque iterum pinnatis, articulis pinnarum diametro 3-4-plo, pinnularum 2-plo longioribus.

Syn. Phyllodictyon pulcherrimum, J. E. Gray, Journ. Bot. (i 886$)$, p. 70.

Hab. in sinu Mexicano legit cl. Archibald Menzies ${ }^{1}$ !

5. Str. tenzis, Zanard. in Nuovo Giorn. Bot. Ital. (I 878 ), p. 39. Stipes laevis pusillus reticulo pulcherrimo, cordatoovato, tenuissimo ( $\$$ unc. et longo et lato) coronatus; filis bipinnatis articulis diametro 2-3-plo longioribus.

Hab. ad Sorong, Nova Guinea legit O. Beccari!

6. Str. delicatula, Kütz. Tab. Phyc., Bd. xvi, Tab. 2. Stipes laevis, simplex vel ramosus, pusillus, reticulo subpyramidato ( $\mathrm{I}-2$ uncias longo), coronatus; filis distiche pluries pinnatis, pinnis pinnulisque oppositis horizontaliter patentibus, hic illic applicatis.

Species quam maxime variabilis.

Syn. Cladophora? anastomosans, Harv. Phyc. Austr., Tab. ci.

Hab. ad Novam Caledoniam leg. Viellard; ad oras occidentales Novae Hollandiae leg. Harvey! ad Ceylonam leg. Ferguson! ad ins. Guadeloupe leg. Mazé!

Var. Caracasana, Grunow, in lit. filis reticuli regulariter bipinnatis.

Hab. ad Cap. Blanco Caracas leg. Gollma!

Species exclusa.

Str. scoparia, Kütz. Tab. Phyc. Bd. xvi, Tab. $2=$ Apjohnia laete-virens, Harv.

Cl. Grunow misit sub nomine Valoniae radicantis, Grun. (Adelaide, Nova Hollandia) et Valoniae rhizophorae, Grun. et Picc. (Suakin in mari rubro) duas species immaturas forsan Struveae.

1 On searching Menzies' own Herbarium in Edinburgh Botanic Garden we found another specimen of $S$. palcherrima-unfortunately even more incomplete than the one referred to. It however exhibits perfectly the beautiful structure of the frond, and bears the additional information that it was dredged from 20 fathoms. 


\section{EXPLANATION OF FIGURES IN PLATE XVI.}

Illustrating Messrs. Murray and Boodle's paper on the genus Strutvea.

Fig. 1. a, Struvea plumosa (nat. size). $\quad b, c, d$, Stages in development of $S$. plumosa (nat. size). $e$, Part of nearly mature frond $(\times 6) . f$, Apex of filament with tenaculum $(\times 60) . g$, Melobesia coating of part of stalk $(\times 5) . h$, Striations of membrane of midrib (highly magnified).

Fig. 2. a, S. macrophylla (nat. size). b, Part of frond of S. macrophylla ( $\times 2$ ).

Fig. 3. $a, S$. ramosa, unbranched specimen (nat. size). $b$. Branched specimen showing rugae (nat. size). $c$, Part of frond of $S$. ramosa $(\times 6) . d$, Tip of filament with tenaculum; the rootlets are seen partly in surface view ( $\times 130)$. $e$, Pinnule bearing two tenacula $(\times 30)$. $f$, Pinnule forming two branches $(\times 30) . g$, Base of frond showing position of clamps $(\times 30)$. $h$, One of the clamps more highly magnified ( $x$ I 30 ).

Fig. 4. $a, S$. pulcherrima restored and reduced to one fourth. $b$, Part of frond $(\times 6)$.

Fig. 5. $a, S$. tenuis (nat. size). b, The same magnified $(\times 10) . \quad c$, Upper part of frond $(\times 40) . \quad d$, First stage in formation of the frond $(\times 35)$.

Fig. 6. $a, S$. delicatula (nat. size). $b$, Part of frond $(x 6) . c$, Early stage in formation of frond $(\times 6)$. $d$, Case of prolification $(\times 30)$.

Fig. 7. $a$, S. delicatula var. Caracasana (nat. size). $b$, Part of frond $(\times 6)$.

Fig. 8. $a, S$. delicatzila erect form (nat. size). $b$, Part of frond $(\times 30) . c$, Roots of same $\left(x 3^{\circ}\right)$. 

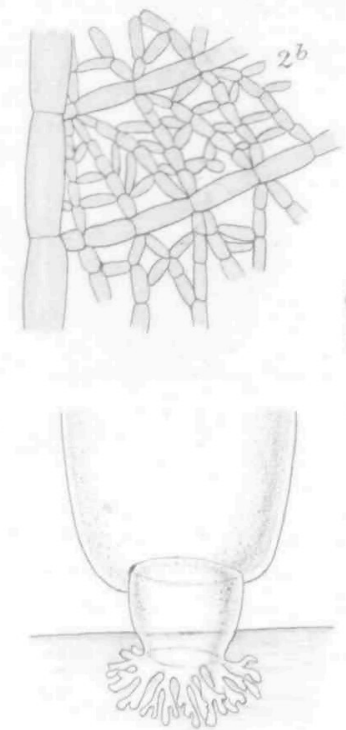

$3^{2}$

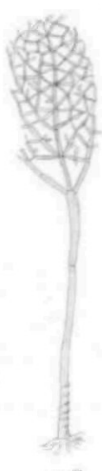

$3^{a}$
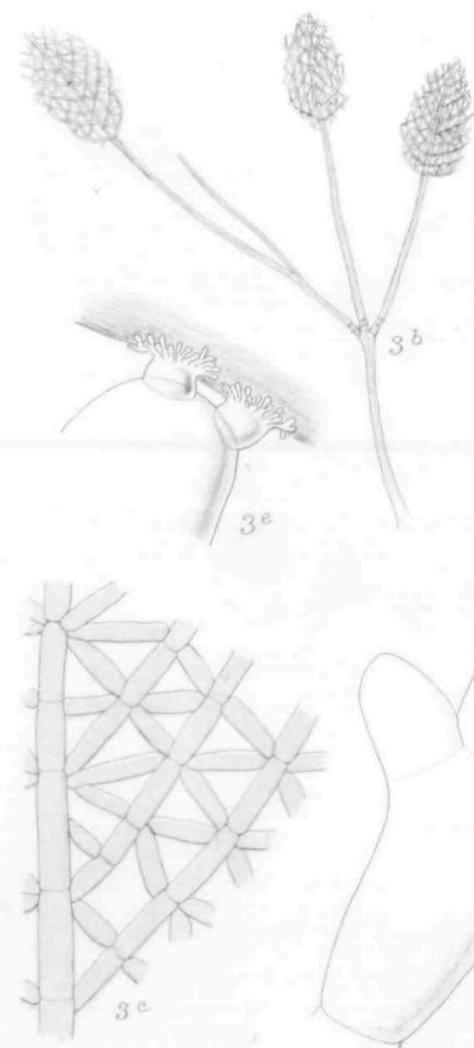
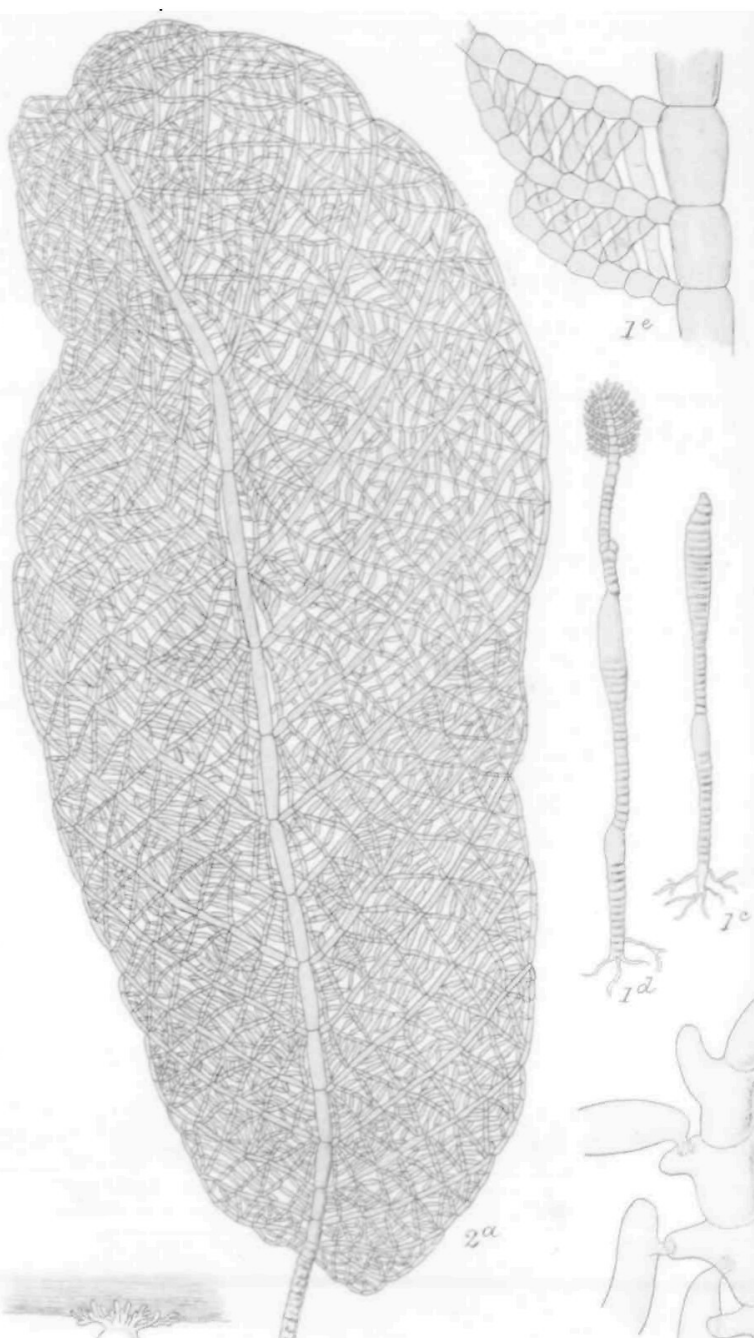

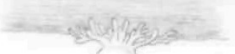
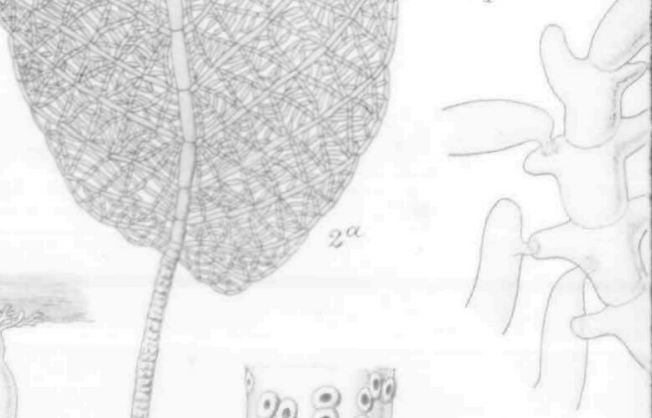

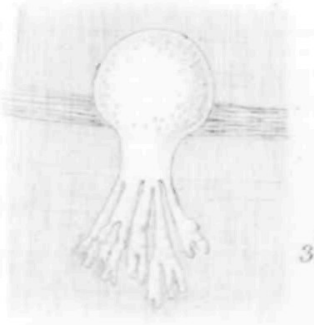

$3^{h}$ 


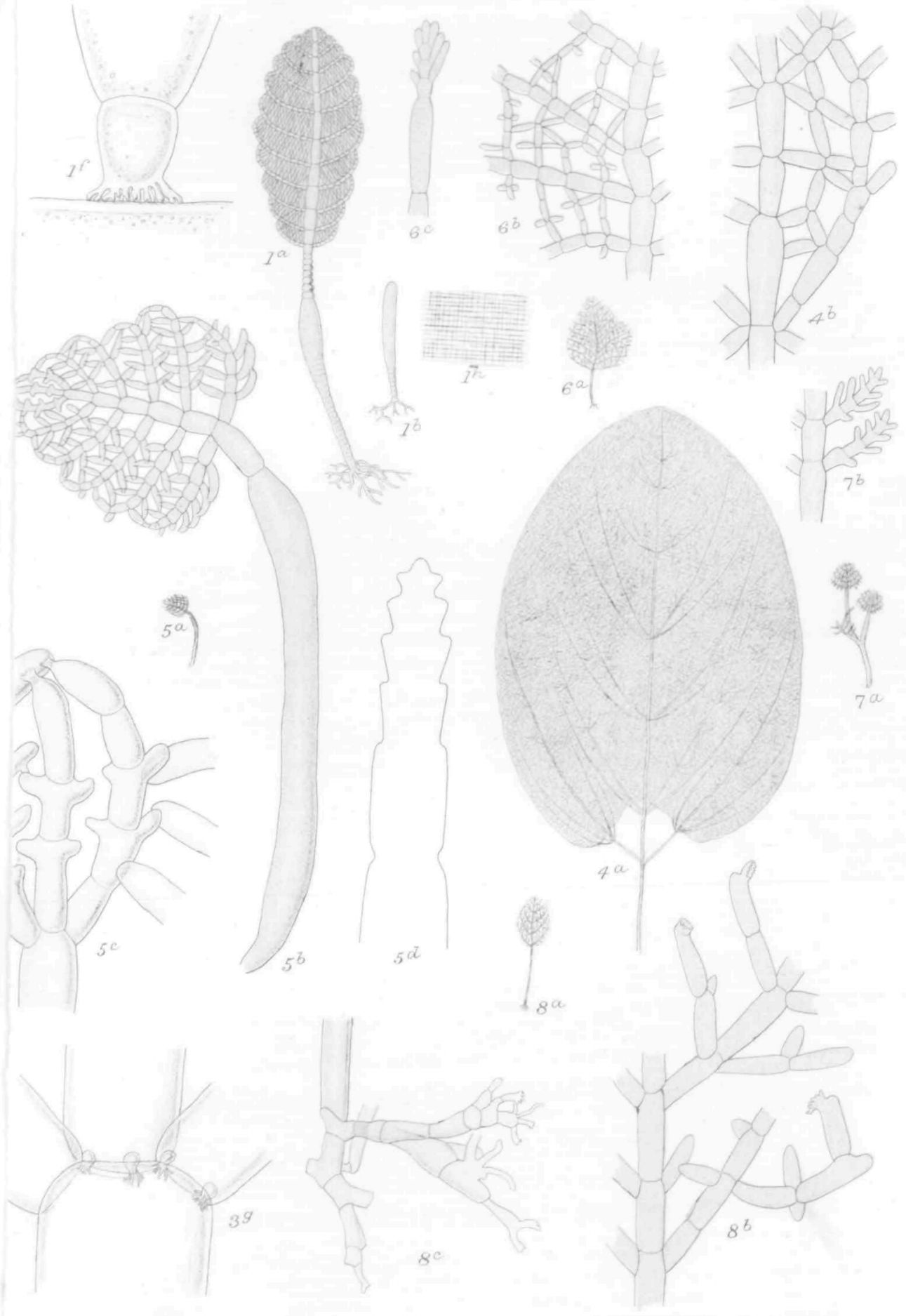

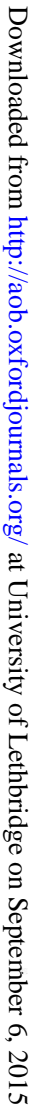




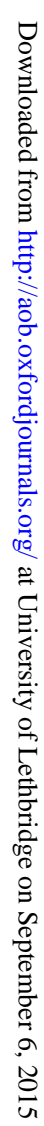

